\title{
Effect of Vermicompost and P Enriched Biocompost on Soil Properties under French bean Crop
}

\author{
Vishakha Paul, Shilva Dhiman* and Y.P. Dubey \\ Department of Soil Science, CSK Himachal Pradesh Krishi Vishvavidyalaya, \\ Palampur, 176062, Himachal Pradesh, India \\ *Corresponding author
}

\section{A B S T R A C T}

Keywords

French bean (Phaseolus vulgaris L.), Vermicomposts

Article Info

Accepted:

16 August 2018

Available Online:

10 September 2018
An experiment was conducted at the experimental farm of Department of Soil Science, CSKHPKV, Palampur by taking French bean crop during kharif, 2009. Biocompost and vermicompost were prepared by using cow dung and weeds and were inoculated with microbial inoculants and rock phosphate. Biocompost and vermicompost were analysed and the best one among nine composts prepared i.e. 50\% each of cowdung and substrate+ $2 \%$ rock phosphate + inoculants and three vermicomposts i.e. the one prepared by using Eupatorium waste, on the basis of nutrient content, was selected and applied to the crop in combination with fertilizers depending upon the treatment. There were twelve treatments and three replications in randomized block design. an increase in $\mathrm{pH}$, organic carbon (12.42 $\mathrm{g} \mathrm{kg}^{-1}$ ), CEC [12.84 cmol $\left(\mathrm{p}^{+}\right) \mathrm{kg}^{-1}$ ], available $\mathrm{N}, \mathrm{P}$ and $\mathrm{K}\left(467.6 \mathrm{~kg} \mathrm{ha}^{-1}, 16.4 \mathrm{~kg}\right.$ $\mathrm{ha}^{-1}$ and $191.5 \mathrm{~kg} \mathrm{ha}^{-1}$ respectively), biomass carbon $\left(89.34 \mu \mathrm{g} \mathrm{g}^{-1}\right)$, water holding capacity, field capacity, permanent wilting point and total microbial count was observed in the treatments where vermicompost and biocompost were applied @ $15 \mathrm{t} \mathrm{ha}^{-1}$.

\section{Introduction}

French bean (Phaseolus vulgaris L.), a member of family fabaceae, is one of the most ancient and popular warm season vegetable crop grown worldwide for its green pods. It is an important source of protein, calcium, iron and vitamins in human diet. The crop is known by various names as French bean, common bean, snap bean, kidney bean and navy bean. In India, it is commercially cultivated in Himachal Pradesh, Jammu and Kashmir, hills of Uttrakhand, North-Eastern states and peninsular India, covering an area of about 1,50,000 ha with annual production of $4,20,000$ tonnes and ranks $4^{\text {th }}$ in green bean production in the world. Its cultivation in Northern Indian plains is rather restricted in account of limited period of favorable weather conditions. It occupies an area of 3,197 ha with annual production of 33,112 metric tonnes in Himachal Pradesh. Biocompost and vermicompost supplement the nutrient requirements of crops. Concerning the economic sustainability, the low cost of compost is useful to farmer as well to human society. Vermicompost is reported to be rich in nutrient elements (Jambhekar, 1992) and biocompost also contains high amount of nutrients than ordinary compost or FYM. 
Organic manuring systems fitted effectively in intensive cropping systems are likely to play a decisive role in sustainable agriculture.

\section{Materials and Methods}

An experiment was conducted at the experimental farm of Department of Soil Science, CSKHPKV, Palampur by taking French bean crop during kharif, 2009. Biocompost and vermicompost were prepared by using cow dung and weeds and were inoculated with microbial inoculants and rock phosphate. Nine biocomposts and three vermicomposts were prepared and analyzed and the best one among nine composts prepared i.e. 50\% each of cow dung and substrate $+2 \%$ rock phosphate + inoculants and three vermicomposts i.e. the one prepared by using Eupatorium waste, on the basis of nutrient content, was selected and applied to the crop in combination with fertilizers depending upon the treatment. There were twelve treatments and three replications in randomized block design. The field experiment was conducted on French bean using following treatments: $\mathrm{T}_{1}: 100 \% \mathrm{P}+\mathrm{N}$ fixer $+\mathrm{P}$ solubilizer, $\mathrm{T}_{2}: 100 \% \mathrm{P}+100 \% \mathrm{~N}$, $\mathrm{T}_{3}: 75 \% \mathrm{P}+\mathrm{N}$ fixer $+\mathrm{P}$ solubilizer, $\mathrm{T}_{4}: 75 \% \mathrm{P}$ $+100 \% \mathrm{~N}, \mathrm{~T}_{5}: 100 \% \mathrm{P}+\mathrm{N}$ fixer $+\mathrm{P}$ solubilizer +biocompost, $\mathrm{T}_{6}: 75 \% \mathrm{P}+100 \% \mathrm{~N}$ + biocompost, $\mathrm{T}_{7:} 100 \% \mathrm{P}+100 \% \mathrm{~N}+$ biocompost, $\mathrm{T}_{8}: 75 \% \mathrm{P}+$ inoculation with $\mathrm{N}-$ fixer and $\mathrm{P}$ solublizers + biocompost, $\mathrm{T}_{9}$ : $100 \% \mathrm{P}+$ inoculation with $\mathrm{N}$-fixer and $\mathrm{P}$ solublizer + vermicompost, $\mathrm{T}_{10}: 100 \% \mathrm{P}+$ $100 \% \mathrm{~N}+$ vermicompost, $\mathrm{T}_{11}: 75 \% \mathrm{P}+$ inoculation with $\mathrm{N}$-fixer and $\mathrm{P}$ solublizer + vermicompost, $\mathrm{T}_{12}: 75 \% \mathrm{P}+100 \% \mathrm{~N}+$ vermicompost.

\section{Results and Discussion}

\section{Composts}

The vermicompost exhibited higher values of total nitrogen, phosphorus, potassium and microbial biomass nitrogen whereas $P$ enriched biocompost exhibited higher values of organic carbon, $\mathrm{C}$ : $\mathrm{N}$ ratio, microbial population and biomass sulphur. The values of biomass nitrogen were same in both the composts. The soil sample before sowing of crop was taken and was analyzed for physical, chemical and microbiological properties. The soil was having texture silty clay loam, $\mathrm{pH}$ 5.2 , cation exchange capacity $11.0 \mathrm{cmol}\left(\mathrm{p}^{+}\right)$ $\mathrm{kg}^{-1}$, organic carbon $10.5 \mathrm{~g} \mathrm{~kg}^{-1}$, available $\mathrm{N}, \mathrm{P}$ and $\mathrm{K} 390 \mathrm{~kg} \mathrm{ha}^{-1}, 11.5 \mathrm{~kg} \mathrm{ha}^{-1}$ and $169.12 \mathrm{~kg}$ $\mathrm{ha}^{-1}$ respectively, microbial biomass carbon $65.80 \mu \mathrm{g} \mathrm{g}^{-1}$ and microbial count as $3.2 \times 10^{7} \mathrm{cfu}$ $\mathrm{g}^{-1}$ bacteria, $2.9 \times 10^{5} \mathrm{cfu} \mathrm{g}^{-1}$ fungi and $19 \times 10^{4}$ cfu $\mathrm{g}^{-1}$ actinomycetes. Similar results were reported by Jambhekar (1992), Saxsena et al., (1998), Vasanthi and Kumaraswamy (1999), Sarangthen and Singh (2005), Manna et al., (1997), Thakur and Sharma (1998) and Manna and Ganguly (1999).

\section{Soil properties}

After the harvest of crop, representative soil samples from each plot were taken from the depths of $0-0.15 \mathrm{~m}$ and were analyzed for chemical, physical and microbiological properties of soil.

\section{Soil reaction $(\mathbf{p H})$}

The $\mathrm{pH}$ of the soil samples $0-0.15 \mathrm{~m}$ varied between 5.2 and 5.4 and the results revealed that there was an increase in $\mathrm{pH}$ after application of biocompost and vermicompost over the recommended dose of fertilizers. Increase in $\mathrm{pH}$ by the application of vermicompost was also recorded by Yagi et al., (2003).

\section{Cation exchange capacity}

Cation exchange capacity in the soil from 0 $0.15 \mathrm{~m}$ varied between $11.15 \mathrm{cmol}\left(\mathrm{p}^{+}\right) \mathrm{kg}^{-1}$ and $12.84 \mathrm{cmol}\left(\mathrm{p}^{+}\right) \mathrm{kg}^{-1}$. The highest value of cation exchange capacity was recorded in the 
treatment $100 \%$ NPK + vermicompost followed by $100 \%$ NPK treatment. The highest value of cation exchange capacity was recorded in the treatment $100 \% \mathrm{P}$ and $\mathrm{K}+$ biofertilizers + PEB $+100 \% \mathrm{~K}$ followed by $100 \% \mathrm{P}$ and $\mathrm{K}+$ biofertilizer + vermicompost. The cation exchange capacity was significantly higher in the above mentioned treatments than the recommended dose of fertilizers. Lowest value of cation exchange capacity at the depth of $0-0.15 \mathrm{~m}[11.15 \mathrm{cmol}$ $\left(\mathrm{p}^{+}\right) \mathrm{kg}^{-1}$ ] was observed in the treatment $75 \% \mathrm{P}$ $+100 \% \mathrm{~N}$ and $\mathrm{K}+$ vermicompost. Cation exchange capacity increased with the application of vermicompost in $0-0.15 \mathrm{~m}$ depth of soil. There is release of cations with the decomposition of organic matter which would have increased the cation exchange capacity. Similar results were given by Yagi et al., (2003). An increase was observed in case of cation exchange capacity in the treatment $100 \%$ NPK + vermicompost over $100 \%$ NPK treatment in $0-0.15 \mathrm{~m}$ depth of soil.

\section{Organic carbon}

The values of the organic carbon content of the soil are presented in the table 1. Results show that the values of organic carbon varied between 10.78 and $12.42 \mathrm{~g} \mathrm{~kg}^{-1}$ in $0-0.15 \mathrm{~m}$ soil. Highest organic carbon content was recorded in the treatment $75 \% \mathrm{P}+$ biofertilizer $+\mathrm{P}$ enriched biocompost $+100 \% \mathrm{~K}$ followed by $75 \% \mathrm{P}+100 \% \mathrm{~N}$ and $\mathrm{K}+\mathrm{P}$ enriched biocompost treatment which was 1.5 percent higher than $100 \%$ NPK treatment. The organic carbon content in 0-0.15 m depth of soil in the treatment $75 \% \mathrm{P}+$ biofertilizers $+\mathrm{P}$ enriched biocompost $+100 \% \mathrm{~K}$ was found to be significantly higher than the $100 \%$ NPK treatment.

Application of vermicompost also increased the organic carbon content in the soil over recommended dose of fertilizers. Vermicompost is organic in nature and originally rich in organic carbon content. On the other hand, worms increased organic carbon in the cast because of selective feeding on non humified material within the soil matrix and secretion of mucopolysaccharide in their gut. The results were similar to those presented by Singh et al., (2007), Anwar et al., (2005) and Yagi et al., (2003).

\section{Available nitrogen}

The available $\mathrm{N}$ content was found highest in the treatment $100 \% \mathrm{P}$ and $\mathrm{K}+$ biofertilizer $+\mathrm{P}$ enriched biocompost in 0-0.15 $\mathrm{m}$ depth of soil. The available nitrogen content in $0-0.15 \mathrm{~m}$ soil depth was found significantly higher in the treatment $100 \% \mathrm{P}$ and $\mathrm{K}+$ biofertilizer $+\mathrm{P}$ enriched biocompost than 100\% NPK treatment. Available nitrogen was recorded to be lowest $\left(412.9 \mathrm{~kg} \mathrm{ha}^{-1}\right)$ in the treatment $100 \%$ NPK + vermicompost.

\section{Available phosphorus}

The available $\mathrm{P}$ content in $0-0.15 \mathrm{~m}$ depth of soil ranged between $11.0 \mathrm{~kg} \mathrm{ha}^{-1}-16.4 \mathrm{~kg}^{-}$

1. The available $\mathrm{P}$ content was recorded highest in the treatment $100 \% \mathrm{P}$ and $\mathrm{K}+$ biofertilizers + vermicompost @15 t ha-1 which was 24.24 per cent higher than the $100 \%$ NPK treatment in $0-0.15 \mathrm{~m}$ and 42.61 per cent higher than initial soil. A significant increase in available $\mathrm{P}$ content was recorded in the treatment $100 \% \mathrm{P}$ and $\mathrm{K}+$ biofertilizer + vermicompost over $100 \%$ NPK treatment. The application of $100 \% \mathrm{P}$ through fertilizers, vermicompost and $\mathrm{P}$ solubilizers increased the available P content of the soil. $75 \% \mathrm{P}+100 \%$ $\mathrm{N}$ and $\mathrm{K}+\mathrm{P}$ enriched biocompost treatment recorded lowest values of available $P(11.0 \mathrm{~kg}$ $\mathrm{ha}^{-1}$ ) content at the depth of $0-0.15 \mathrm{~m}$. On decomposition of organic matter by various microorganisms, the organic phosphorus is converted slowly to inorganic form. The increase in available $\mathrm{P}$ content of soil can also be explained on the basis of results of Negi 
(1986) who reported that supply of high levels of phosphorus helps in the build-up of available $\mathrm{P}$ of the soil.

\section{Potassium}

The available $\mathrm{K}$ content was found highest in the treatment $75 \% \mathrm{P}+$ biofertilizers + vermicompost $+100 \% \mathrm{~K}$ in $0-0.15 \mathrm{~m}$ depth of soil which was 20.3 per cent and 25.4 per cent higher than $100 \%$ NPK treatment respectively.

Available potassium was recorded lowest in the treatment $100 \% \mathrm{P}$ and $\mathrm{K}+$ biofertilizer + vermicompost (144.4 $\mathrm{kg} \mathrm{ha}^{-1}$ ) at the depth of 0-0.15 m. Application of vermicompost increased the available potassium content of soil. Similar reports were reported by Patil and Bhilare (2001), Bhalerao et al., (2002), Chettri et al., (2004) and Sitangshu and Mondal (2004). Likewise, significant improvement in fertility status of the soils due to addition of FYM or crop residues have also been reported by Singh et al., (1997) and Roy et al., (2001). Anwar et al., (2005) also reported higher values of organic carbon, available $\mathrm{N}$ and $\mathrm{P}$ in the plots receiving organic manures in addition to mineral fertilizer compared to those plots treated with chemical fertilizers alone. The potassium content of the vermicompost and biocompost is high which would have also increased the available $\mathrm{K}$ content in soil. The results are similar to the findings of Kapur et al., (1981) Ganai and Singh (1988), Pati Ram (1994) and Bhalerao et al., (2002). Also the uptake of potassium in the treatment $75 \% \mathrm{P}+100 \% \mathrm{~K}+$ biofertilizer + vermicompost was less so the content of potassium was higher in the soil.

\section{Microbiological properties of soil}

\section{Total microbial count}

\section{Bacterial population}

The bacterial population in the soil was found to be significantly higher in the treatment $100 \% \mathrm{P}$ and $\mathrm{K}+$ biofertilizer $+\mathrm{P}$ enriched biocompost in $0-0.15 \mathrm{~m}$ depths which was 23.68 per cent higher than $100 \%$ NPK treatment and was at par with $75 \% \mathrm{P}+$ biofertilizer $+\mathrm{P}$ enriched biocompost $+100 \%$ $\mathrm{K}$ and $100 \% \mathrm{P}$ and $\mathrm{K}+$ biofertilizer treatment respectively and 46.87 per cent higher than initial status of soil.

Table.1 Effect of different treatments on chemical and microbiological properties of soil after harvest of French bean

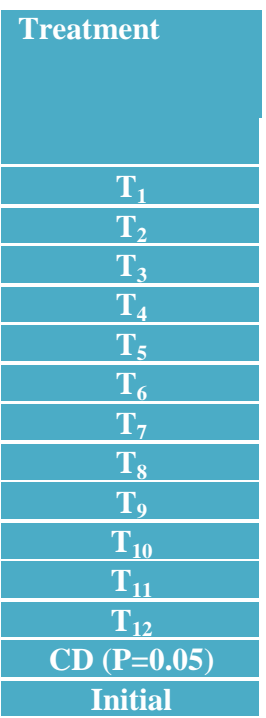

\begin{tabular}{|l|l|l|l|}
\hline pH & CEC & $\begin{array}{l}\text { Organic } \\
\text { carbon }\end{array}$ & $\begin{array}{c}\text { A vailable } \\
\text { N }\left(\mathrm{kg} \mathrm{ha}^{-1}\right)\end{array}$ \\
\hline & & & \\
\hline 5.2 & 11.20 & 10.92 & 449.4 \\
\hline 5.2 & 11.50 & 10.78 & 420.3 \\
\hline 5.3 & 11.18 & 10.82 & 424.0 \\
\hline 5.3 & 11.75 & 10.88 & 453.8 \\
\hline 5.4 & 12.78 & 11.80 & 467.6 \\
\hline 5.4 & 12.60 & 12.29 & 423.4 \\
\hline 5.4 & 12.78 & 11.82 & 452.7 \\
\hline 5.3 & 11.22 & 12.42 & 434.5 \\
\hline 5.3 & 12.12 & 11.57 & 449.4 \\
\hline 5.4 & 12.84 & 11.73 & 412.9 \\
\hline 5.4 & 12.33 & 11.40 & 459.9 \\
\hline 5.3 & 11.15 & 11.20 & 444.2 \\
\hline NS & $\mathbf{0 . 2 8}$ & $\mathbf{0 . 8 0}$ & $\mathbf{3 2 . 5 7}$ \\
\hline 5.2 & 11.00 & -- & 390.0 \\
\hline
\end{tabular}

\begin{tabular}{|c|}
\hline $\begin{array}{c}\text { A vailabl } \\
\text { e P }(\mathrm{kg} \\
\left.\text { ha }^{-1}\right)\end{array}$ \\
\hline \\
\hline 15.3 \\
\hline 13.2 \\
\hline 14.1 \\
\hline 12.4 \\
\hline 15.8 \\
\hline 11.0 \\
\hline 14.4 \\
\hline 15.4 \\
\hline 16.4 \\
\hline 13.8 \\
\hline 14.1 \\
\hline 14.8 \\
\hline 1.15 \\
\hline 11.5 \\
\hline
\end{tabular}

\begin{tabular}{|c|c|c|c|c|}
\hline $\begin{array}{c}\text { Availabl } \\
\text { e K (kg } \\
\left.\text { ha }^{-1}\right)\end{array}$ & $\begin{array}{l}\text { Bacteria (X } \\
10^{7} \text { cfu }^{-1} \\
\text { soil) }\end{array}$ & $\begin{array}{l}\text { Fungi (X } \\
10^{5} \mathrm{cfu}^{-1} \\
\text { soil) }\end{array}$ & $\begin{array}{l}\text { Actinomyce } \\
\operatorname{tes}\left(X_{10} 10^{4}\right. \\
\text { cfu g }^{-1} \text { soil) }\end{array}$ & $\begin{array}{c}\text { Microbial } \\
\text { biomass carbon } \\
\left(\mu \mathrm{g} \mathrm{g}^{-1}\right)\end{array}$ \\
\hline \multicolumn{5}{|c|}{ 0-0.15 m } \\
\hline 162.2 & 4.0 & 3.2 & 22 & 75.08 \\
\hline 159.2 & 3.8 & 3.3 & 23 & 69.85 \\
\hline 158.2 & 3.7 & 3.4 & 24 & 80.78 \\
\hline 147.0 & 3.8 & 3.4 & 25 & 78.88 \\
\hline 189.2 & 4.7 & 4.1 & 23 & 88.39 \\
\hline 166.6 & 4.4 & 4.2 & 25 & 78.88 \\
\hline 180.5 & 4.3 & 4.6 & 29 & 89.34 \\
\hline 155.2 & 4.6 & 4.1 & 28 & 75.56 \\
\hline 144.4 & 4.2 & 3.5 & 27 & 86.01 \\
\hline 166.1 & 4.1 & 3.2 & 21 & 67.00 \\
\hline 191.5 & 4.1 & 3.3 & 22 & 75.56 \\
\hline 171.2 & 4.2 & 4.3 & 26 & 79.83 \\
\hline 20.80 & 0.30 & 0.30 & 2.38 & 7.55 \\
\hline 169.1 & 3.2 & 2.9 & 19 & 65.80 \\
\hline
\end{tabular}


Table.2 Effect of different treatments on physical properties of soil after harvest of French bean

\begin{tabular}{l|l|l|l|} 
Treatments & Water holding capacity $(\%)$ & Field capacity $(\%)$ & Permanent wilting point $(\%)$ \\
\hline
\end{tabular}

\begin{tabular}{|c|c|c|c|}
\hline \multicolumn{4}{|c|}{$0-0.15 \mathrm{~m}$} \\
\hline$T_{1}$ & 56.1 & 25.16 & 16.58 \\
\hline $\mathrm{T}_{2}$ & 56.0 & 25.15 & 16.38 \\
\hline $\mathbf{T}_{\mathbf{3}}$ & 56.2 & 25.35 & 16.39 \\
\hline $\mathrm{T}_{4}$ & 56.2 & 25.34 & 16.24 \\
\hline$T_{5}$ & 56.1 & 25.51 & 16.40 \\
\hline$T_{6}$ & 56.1 & 25.80 & 16.15 \\
\hline$T_{7}$ & 56.2 & 25.30 & 16.33 \\
\hline $\mathrm{T}_{8}$ & 56.2 & 25.10 & 16.48 \\
\hline$T_{9}$ & 56.8 & 26.69 & 17.58 \\
\hline$\overline{T_{10}}$ & 57.2 & 26.65 & 17.72 \\
\hline$T_{11}$ & 57.1 & 26.52 & 17.66 \\
\hline $\mathbf{T}_{12}$ & 57.2 & 26.84 & 17.42 \\
\hline $\mathrm{CD}(\mathrm{P}=0.05)$ & 0.37 & 0.89 & 0.43 \\
\hline Initial & 56 & 25.81 & 16.10 \\
\hline
\end{tabular}

The biocompost contains higher count of bacteria over vermicompost which would have increased bacterial population in soil also.

\section{Fungal population}

The fungal population was found significantly higher than rest of the treatments i.e. $4.6 \mathrm{X}$ $10^{5} \mathrm{cfu} \mathrm{g}^{-1}$ soil in the treatment recommended $\mathrm{NPK}+\mathrm{P}$ enriched biocompost in $0-0.15 \mathrm{~m}$ soil depth. It was higher than $100 \%$ recommended dose of fertilizers and initial soil. The biocompost contains highest fungal population which has increased the fungal population in the $0-0.15 \mathrm{~m}$ depth of soil.

\section{Actinomycetes population}

The population of actinomycetes was found highest in the treatments where vermicompost was added $(0-0.15 \mathrm{~m})$. There was an increase of 20.88 per cent over $100 \%$ NPK treatment. The actinomycetes population in the treatments receiving vermicompost was significantly higher than $100 \%$ NPK treatment and initial soil. Similar results for increasing in microbial population were also reported by Kale et al., (1992), Malewar et al., (1999) and Hangarge et al., (2004).

\section{Microbial biomass carbon}

The values of biomass carbon varied between 67 and $89.34 \mu \mathrm{g} \mathrm{g}^{-1}$ soil in $0-0.15 \mathrm{~m}$ depth. The highest value of biomass carbon was recorded in the treatment $100 \% \mathrm{NPK}+\mathrm{P}$ enriched biocompost in $0-0.15 \mathrm{~m}$ soil. Lowest values of biomass carbon were observed in the treatment $100 \% \mathrm{NPK}+$ vermicompost at the depth of $0-0.15 \mathrm{~m}$.

A significant increase in the values of biomass carbon was recorded in the treatments $100 \%$ NPK $+\mathrm{P}$ enriched biocompost and $100 \% \mathrm{P}$ and $\mathrm{K}+$ biofertilizer $+\mathrm{P}$ enriched biocompost in $0-0.15 \mathrm{~m}$ which was 27.9 per cent higher over $100 \%$ NPK treatment. Biofertilizer based integrated nutrient management package treatment showed the highest content of soil microbial biomass carbon, which was at par with the 
treatment of $50 \%$ recommended dose of fertilizers plus 50\% N through FYM (Gogoi et al., 2010). Findings of Ghoshal and Singh (1994) and Rao (2007) supported such results. The organic carbon content in this treatment is higher which would have increased the biomass carbon in this treatment.

\section{Physical properties of soil}

\section{Water holding capacity}

The water holding capacity was recorded highest in the treatment $75 \% \mathrm{P}+100 \% \mathrm{~N}$ and $\mathrm{K}+$ vermicompost i.e. 57.2 per cent which was significantly higher than $100 \%$ NPK treatment and $75 \% \mathrm{P}+100 \% \mathrm{~N}$ and $\mathrm{K}+\mathrm{P}$ enriched biocompost treatment. The lowest water holding capacity (56.0 per cent) was recorded in the treatment $100 \% \mathrm{NPK}$ at the depth of 0-0.15 m.

\section{Field capacity}

The moisture content at field capacity was recorded highest i.e. 26.84 per cent in the treatment $75 \% \mathrm{P}+100 \% \mathrm{~N}$ and $\mathrm{K}+$ vermicompost which was significantly higher than $100 \%$ recommended dose of fertilizers and $75 \% \mathrm{P}+100 \% \mathrm{~N}$ and $\mathrm{K}+\mathrm{P}$ enriched biocompost treatment. Lowest field capacity (25.10 per cent) was recorded in the treatment $75 \% \mathrm{P}+$ biofertilizers $+\mathrm{P}$ enriched biocompost $+100 \% \mathrm{~K}$ at the depth of $0-0.15$ m.

\section{Permanent wilting point}

The moisture content at permanent wilting point was recorded highest i.e. 17.72 per cent in the treatment $100 \% \mathrm{NPK}+$ vermicompost at $0-0.15 \mathrm{~m}$ depth. The moisture content at permanent wilting point was significantly higher than $100 \%$ recommended dose and $100 \%$ NPK $+\mathrm{P}$ enriched biocompost treatment at $0-0.15 \mathrm{~m}$ depth. Permanent wilting point was recorded lowest in the treatments $75 \% \mathrm{P}+100 \% \mathrm{~N}$ and $\mathrm{K}+\mathrm{P}$ enriched biocompost (16.15 per cent) (Table 2).

Water holding capacity and moisture content at field capacity and permanent wilting point was increased by the use of vermicompost. This could be ascribed to the improvement in structural condition of soil due to application of vermicompost with inorganics (Bhatnagar et al., 1992). Since the application of fertilizers and organic matter together resulted in improvement in soil organic carbon therefore improvement in soil water holding capacity and plant available water in soil is expected. Also the higher water holding capacity of the added organic matter in turn might have increased the water holding capacity of soil. Similar results were also reported by Hangarge (2002), Selvi et al., (2005) and Deshmukh et al., (2007).

The applications of either vermicompost or biocomposts prove beneficial to maintain the soil health in terms of soil physical, chemical and microbiological properties as compared to the application of inorganic fertilizers alone.

\section{References}

Anwar M, Patra DD, Chand S, Alpesh K, Naqvi AA and Khanuja SPS. 2005. Effect of organic manures and inorganic fertilizer on growth, herb and oil yield, nutrient accumulation, and oil quality of French Basil. Communications in Soil Science and Plant Analysis 36(13-14): 1737-1746

Bhalerao GA, Abdul H, Jiotode DJ and Mohd. Sajid. 2002. Quality, uptake and availability of $\mathrm{N}, \mathrm{P}$ and $\mathrm{K}$ as influenced by integrated nutrient management with vermicompost in rainfed sorghum. Research on Crops 3(3): 498-501 
Bhatnagar VK, Kundu S and Vedprakash K. 1992. Effect of long term manuring and fertilization on soil physical properties under soybean (Glycine max)-wheat (Triticum aestivum) cropping sequence. Indian Journal of Agricultural sciences 62(1): 212-214

Chettri M, Mondal SS and Konar A.2004. Integrated nutrient management for enhancing productivity and sustaining soil fertility under potato (Solanum tuberosum)-based cropping system in West Bengal. Indian Journal of Agricultural Sciences 74(4): 210-212

Deshmukh PA, Bonde AS, Padekar DG and Band SB. 2007. Long term effect of organics and fertilizers on some physical parameters of soils on vertisols under sorghum-wheat sequence. Journal of Soils and Crops 17(2): 339343

Ganai BA and Singh CM.1988. Effect of farmyard manure applied to rice-wheat rotation on physic-chemical properties of soil. Indian Journal of Agronomy 33(3): 327-329

Ghoshal N and Singh KP. 1994. The influence of soil amendments on the proportion of organic carbon and nitrogen in the microbial biomass in a dryland agroecosystem. Tropical Ecology 35, 309-319

Gogoi B, Barua NG and Baruah TC. 2010. Effect of integrated supply of nutrients on soil microbial biomass carbon in an Inceptisol of Assam. Journal of Indian Society of Soil Science 58(2): 241-244

Hangarge DS, Raut RS, More SD, Birajdar RR and Pholane LP. 2002. Effect of vermicompost and soil conditioner on some physical properties of soil under chilli-spinach system. Journal of Soils and Crops 12(1): 41-45

Jambhekar HA.1992. In proceeding National seminar on organic farming 52-53 MPKB
Kale RD, Mallesh BC, Bano K and Bagyaraj DJ.1992. Influence of vermicompost application on the available macronutrients and selected microbial populations in a paddy field. Soil Biology and Biochemistry 24(12): 13171320

Kapur ML, Rana DS and Sharma KN.1981. Crop yields in a rotation as influenced by farmyard manure and chemical fertilizers. Indian Journal of Agronomy 26(1): 119-121

Malewar GU, Hasnabade AR and Ismail S.1999. Carbon dioxide evolution and microbial population in soil as influenced by organic and NPK fertilizers under sorghum-wheat system. Journal of Maharashtra Agriculture University 24(2): 121-124

Manna MC and Ganguly TK.1999. Composting, an enrichment technology. Indian Farming 49(1): 14-16

Manna MC, Hazra JN, Sinha NB and Ganguly TK.1997. Enrichment of compost by bioinoculate and mineral treatments. Journal of Indian Society of Soil Science 45(4): 831-833

Negi SC. 1986. Studies on the economy of phosphorus with and without FYM manure in wheat-maize sequence. Ph.D Thesis, HPKV, Palampur.

Pati Ram. 1994. Effect of organic manure and nitrogen application on potassium quantity-intensity relationships in an acid inceptisol. Journal of Indian Society of Soil Science 42(1): 136-139

Patil VS and Bhilare RL.2001. Effect of vermicompost prepared from different organic sources on growth and yield of wheat. Journal of Maharashtra Agricultural Universities 25(3): 305306

Rao DLN. 2007. Microbial diversity, soil health and sustainability. Journal of Indian Society of Soil Science 55(4): 392-403 
Sarangthen I and Singh SJ.2005. Recycling of urban wastes as manures and their evaluation in French bean (Phaseolus vulgaris) In: Conference on Soil, Water and Environmental Quality Issue and Strategies 296

Saxena M, Chauhan A and Ashoka NP.1998. Flyash vermicompost from non-ecofriendly organic waste. Pollution Research 17(1): 5-11

Selvi D, Santhy P and Dhakshinamoorthy. 2005. Effect of inorganics alone and in combination with FYM on physical properties and productivity of Vertic Haplustepts under long term fertilization. Journal of Indian Society of Soil Science 53(3): 302-307

Singh A, Nehra BK, Khurana SC and Singh N. 1997. Influence of plant density and fertility level on growth and yield in seed crop of potato. Journal of Indian Potato Association 24(1-2): 17-23

Singh KP, Srivastava TK, Singh PN and Archana Suman. 2007. Enhancing soil fertility, microbial activity and sugarcane (Saccharum officinarum) productivity through organics in subtropical conditions. The Indian Journal of Agricultural sciences 77(2): 84-87

Thakur S and Sharma LR. 1998. Effect of rock phosphate enrichment and Azotobacter inoculation on the transformation of nitrogen during composting. Journal of the Indian Society of Soil Science 46(2): 228-231

Vasanthi D and Kumarswami K. 1999. Efficacy of vermicompost to improve soil fertility and rice yield. Journal of Indian Society of Soil Science 47(2): 268-272

Yagi R, Ferreira ME, Cruz MCP and Barbosa JC. 2003. Organic matter fractions and soil fertility under the influence of liming, vermicompost and cattle manure. Scientia Agricola. 60(3):549557.

\section{How to cite this article:}

Vishakha Paul, Shilva Dhiman and Dubey Y. P. 2018. Effect of Vermicompost and P Enriched Biocompost on Soil Properties under French bean Crop. Int.J.Curr.Microbiol.App.Sci. 7(09): 2170-2177. doi: https://doi.org/10.20546/ijcmas.2018.709.267 